\title{
Weed species diversity, distribution and infestation trend in small scale irrigated vegetable production area of mid-rift-valley of Ethiopia
}

\begin{abstract}
The gradual worsening of crop pests in mid rift valley of Ethiopia is among the major bottlenecks of vegetable production and productivity. This study was to reveal the contribution of weeds in complicating the pest control in irrigated vegetable production area of Ethiopian. The study was carried out in five districts of East Shewa Zone of mid-Rift valley of Ethiopia (Adami Tulu, Dugda, Liben Chukala, Bora and Lume) known by their high potential irrigated vegetable cultivation. A quadrate sampling and group and individual discussions were used as a tool of data collection. Abundance (A), Dominancy (D), Frequency (F) and Importance Value (IV) and their corresponding Relative value of the species were calculated from the species count and cover data collected. The assessment result showed that 27 weed families comprised 78 weed species were identified. Asteraceae, Poaceae, Amarantaceae, Chenopodaceae and Solonaceae were found the 1st, 2nd, 3rd and 5th important weed families comprising a total of $17,14,5,5$ and 4 species respectively. Information obtained from farmer's interview noted that some weeds which scored low importance value (IV) were found important in influencing the livelihood of the community in one way or another. Amaranthus spinosus, Tribulus cistoides, Euphorbia schimperian, Sorghum arundinacium, Acanthospermum hispidum, Amaranthus hybridus, Parthenium hysterophorus, Snowdenia polystachya and Xanthium spinosum were categorized as weeds known by poisoning livestock in the area. Foeniculum vulgare, Orobanche minor, Parthenium hysterophorus and Portulaca oleracea were categorized among weeds difficult to control using herbicide. Portulaca oleracea, Argemone mexicana, Orobanche minor, Chenopodium murale, Verbesina encelioides, Parthenium hysterophorus, Flaveria trinervia and Launaeaintybacea were listed among weed species currently highly invading the area. Nicandra physaloides, Xanthium strumarium, Parthenium hysterophorus, Datura stramonium and Erucastrumabyssinicum were marked as weeds serving as alternate host for either insects or disease of vegetables. Limited use of crop rotation and herbicide in vegetable fields, unavailability of species specific herbicides, poor field sanitation and fragmented landholding system of the area as a whole were observed as a driving force for the ever expansion of weed invasion in the area.
\end{abstract}

Keywords: adami tulu, alternate host, east shewa zone, oromia, poisoning livestock, resistant to herbicide
Volume 2 Issue I - 2018

\author{
Ayana Etana Terfa \\ Jimma University College of Agriculture and Veterinary \\ Medicine, Ethiopia
}

Correspondence: Ayana Etana Terfa, Jimma University College of Agriculture and Veterinary Medicine, Jimma, Ethiopia, Email ayanaet@gmail.com

Received: November 27, 2017 | Published: February 09, 2018

\section{Introduction}

Mid rift valley of east Shewa, Ethiopia is among the potential commercial irrigated intensive vegetable production areas ${ }^{1}$ supplying a variety of vegetables to every corners of the country. Onion, tomato, maize, kale, hot pepper, watermelon, green bean and head cabbage are among the major vegetable crops widely produced for national and local markets. Okra, cucurbit and sweet melon are also cultivated on small plots. This created a potential job opportunity that result in drifting of job seekers to the area from all parts of the country.

The gradual worsening of crop pests (disease, insect and weed) is becoming the major bottlenecks of vegetable production and productivity ${ }^{2}$ in mid rift valley of Ethiopia. The same author explained as chemical pesticides used to protect pests are predominantly exalting the production cost. Producers have been applying high shower of pesticides with high frequency ${ }^{3}$ and above the recommended dose to overcome the problem; which resulted in accelerated prevalence and severity of pests. This came from application of pesticides without adequate knowledge of the pest and the identity of the pesticide. ${ }^{4}$
Furthermore the practice resulted in ineffective pest control using pesticide due to development of resistance and decimated natural controlling factors.

Although most farmers give less concern for the negative impact that weeds impose on their crop, study results indicated as weeds share up to $45 \%$ of the total annual losses of agricultural products. ${ }^{5}$ Currently weeds are playing significant role in making pest problems very complex. Weeds can play a beneficial role by harboring insect natural enemies and pollinators; however the consequences resulting from weeds harboring crop pests largely outweighs the benefits they potentially provide. Palumbo ${ }^{6}$ noted that weed species found in and around vegetable crops can serve as host plants to many disease and insect pests that can later infest nearby crops.

Therefore bringing importance of weeds contribution in complicating the control of crop pests to attention of every concerned body was found vital. Maynard \& Hochmuth ${ }^{7}$ indicated that accurate identification of the particular weed species is the primary step to control the problems weed impose on agriculture. In addition 
identification of the existing weed flora helps to manage the balance between crop and non-crop vegetation and then maintain the natural enemies of crop pests. ${ }^{8}$ Hence, in this paper the important weed species of the area identified and categorized based on their importance, invasion trend of each weed species, factors supporting weed invasion and the contribution of weeds which so far got insignificant attention were well elucidated.

\section{Materials and methods}

\section{Study area description}

Mid rift valley of Oromia is the part of Great Rift Valley with high potential irrigation based agriculture. Especially, east Shewa zone is known with available water sources for irrigation. Both surface and underground water sources are suitable for irrigation. ${ }^{3}$ The area of irrigation based crop cultivation is increasing from year to year. The very erratic nature of rain fall of the area made irrigation based crop cultivation very preferable. The potential irrigation lands were owned majorly by the irrigation land using farmers' association and large scale private investors. There are also a few individual farmers engaged on using their own irrigation land. Most of the lands owned by the individual farmers and farmers association have been transferred to small scale investors through contractual agreement for one year to several years due to the rise of production cost that small scale farmers can't afford. This approach made the crop pest and soil fertility management very complicated. Especially those producers producing on land of short period contractual agreement were found solely giving priority for productivity of that season leaving aside the issue of pest resistance development and soil fertility degradation. This is in line with Yung et al. ${ }^{9}$ investigation that absentee land owners less likely managed weeds when compared to the resident owners in Montana (Figure 1).

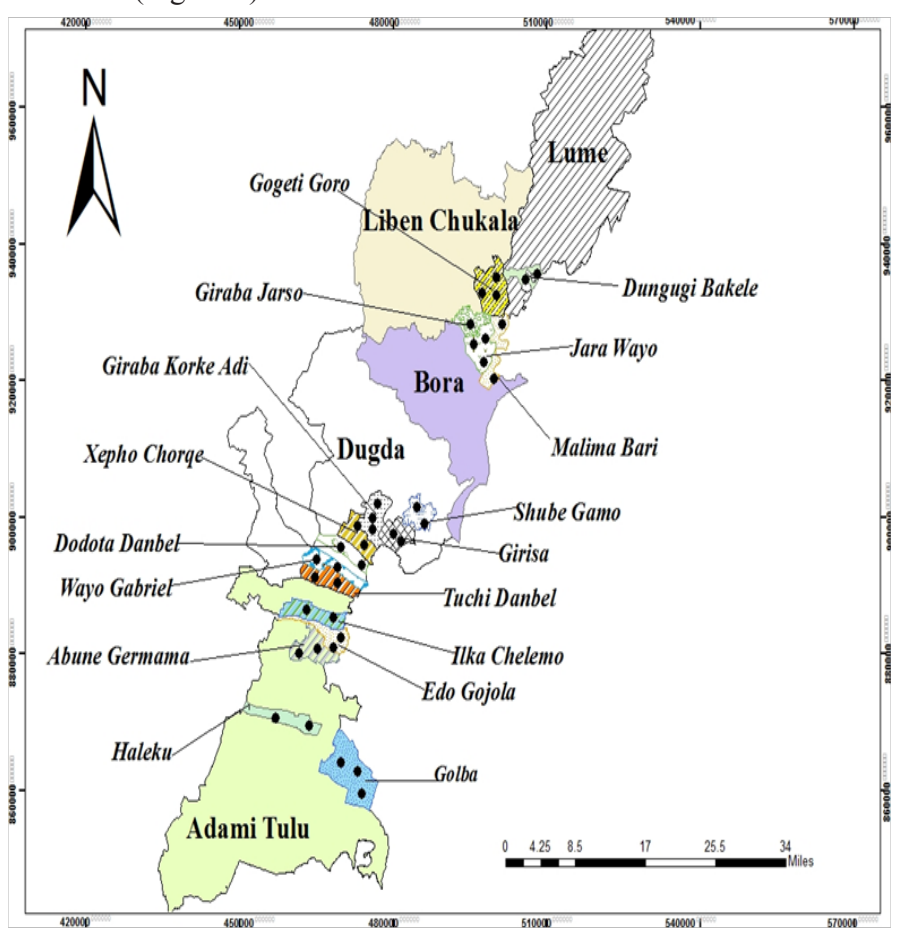

Figure I Map of the study districts and specific irrigation water sheds assessed

\section{Methods}

The study was carried out in five districts of East Shewa Zones of mid-Rift valley of Ethiopia (Adami Tulu, Dugda, Liben Chukala, Bora and Lume) known by their high potential of irrigated farming. Small scale vegetable production areas were purposively selected. In each irrigation watershed representative sample farmers' fields were visited. A quadrate of $1 \mathrm{~m} * 1 \mathrm{~m}$ was thrown randomly. The number of quadrate varies in such a way it can represent the irrigation watershed. A total of 113 sample quadrates were considered. Although water hyacinth (Eichhornia crassipes) weed has been common in the study area, since it was only limited to water body it was not considered in this study. Volunteer crop species were also not considered as weed in this study. All weed species fall in a quadrate were counted per specie and registered. Different weed specie observed outside the quadrate also recorded. Land cover estimate was taken for every species separately. Voucher specimens were collected, coded, pressed and taken to Addis Ababa University National Herbarium and identified to species level following Flora of Ethiopia and Eritrea volumes.

Information about the field management and problems related to weed were collected from the field workers/managers through group discussion based on a checklist prepared. The status of the crop, the weed available, the type of infestation, the infestation level, the level of farmers/workers knowledge about the problem of weed and the control options used were collected. The collected data were summarized using descriptive statistics. Abundance (A), Dominancy (D), Frequency (F) and Importance Value (IV) and their corresponding Relative values of the species were calculated. Importance value (IV) of each species recorded was computed following Shabbir and Bajwa (2006). IV is equal to the sum of the relative Abundance (RA), Relative Dominance (RD) and relative frequency (RF) of species in the stand.

$$
\begin{aligned}
& \mathrm{RA} \%=\frac{\text { Absolute density for a given specie }}{\text { Total absolute density for all species }} X \quad 100 \\
& \mathrm{RD} \%=\frac{\text { Absolute dominancy for a given specie }}{\text { Total absolute dominancy for all species }} \mathrm{X} \quad 100 \\
& \mathrm{RF} \%=\frac{\text { Absolute frequency value for a specie }}{\text { Total absolute frequency for all species }} \mathrm{X} \quad 100 \\
& \mathrm{IV}=\mathrm{RA} \%+\mathrm{RD} \%+\mathrm{RF} \%
\end{aligned}
$$

\section{Result and discussion}

\section{Diversity of weeds}

With the assessment made in irrigated farms of five districts of east Shewa zone (Adami Tullu, Dugda, Liben Chukala, Bora and Lume) 78 weed species comprised in 27plant families were identified. The study result was in line with Eshetu Bekele et al..$^{10}$ investigation that the weed species were composed of a wide range of perennial and annual grasses and broad leaved weeds, sedges, parasitic and invasive weed species. Asteraceae (15spp.), Poaceae (14spp.), Solonaceae (6spp.), Chenopodaceae (5spp.), Amarantaceae (5spp.) and Fabaceae (5spp.) were found the 1st, 2nd, 3rd, 4th, 5th and 6th abundant weed families respectively (Table 1) and share $64 \%$ of the total species of the study area in number. Weeds in family Fabaceae were found richer than Polygonaceae, Brassicaceae and Convolvulaceae in species number but got lesser area coverage. Nicandra physaloides 
( $\mathrm{RF}=73 \%)$, Galinsoga parviflora $(\mathrm{RF}=64 \%)$, Cyperus rotundus $(\mathrm{RF}=64 \%)$, Xanthium strumarium $(\mathrm{RF}=54 \%)$, Amaranthus hybridus $(\mathrm{RF}=56 \%)$, Setaria verticilata $(\mathrm{RF}=50 \%)$, Datura stramonium $(\mathrm{RF}=50 \%)$, Argemone mexicana $(\mathrm{RF}=43 \%)$, Erucastrumabyssinicum $(\mathrm{RF}=45 \%)$, and Xanthium spinosum $(\mathrm{RF}=43 \%)$ were found among the weeds species frequently observed or widely distributed within the study area. Nicandra physaloides $(\mathrm{RD}=13 \%)$, Xanthium strumarium ( $\mathrm{RD}=8 \%)$, Galinsoga parviflora $(\mathrm{RD}=7 \%)$, Datura stramonium $(\mathrm{RD}=6 \%)$, Amaranthus hybridus $(\mathrm{RD}=6 \%)$, Parthenium hysterophorus $(\mathrm{RD}=4 \%)$, Cyperus rotundus $(\mathrm{RD}=4 \%)$, Argemone mexicana $(R D=4 \%)$, Xanthium spinosum $(\mathrm{RD}=3 \%)$ and Portulaca oleracea $(\mathrm{RD}=3 \%)$ were found weed species relatively highly dominated the area. Galinsoga parviflora (RA=18\%), Cyperus rotundus ( $\mathrm{RA}=18 \%)$ Nicandra physaloides $(\mathrm{RA}=7 \%)$, Portulaca oleracea ( $\mathrm{RA}=6 \%)$, Argemone mexicana ( $\mathrm{RA}=5 \%)$, Amaranthus spinosus (RA=4\%), Orobanche minor (RA=4\%), Parthenium hysterophorus $(\mathrm{RA}=4 \%)$, Setaria verticilata $(\mathrm{RA}=3 \%)$ and Cynodon nlemfuensis $(\mathrm{RA}=3 \%$ ) were found among the top ten abundant weed species of the study area (Table 2). Weed species nationally categorized as troublesome noxious weeds and highly constraining agriculture (Digitaria abyssinica, Cynodon spp., Setaria vericillata, Sorghum arundinaceum, Ageratum conzoides, Amaranthus spp., Argemone mexicana, Bidens pilosa, Parthenium hysterophorus, Commelina spp. Convolvolus arvensis, Datura stramonium, Flaveria trinervia, Galinsoga parviflora and Guizota scabra $)^{10}$ were identified as the major weeds of the study area. Nicandira physaloides, Xanthium strumarium, Erucastrumabyssinicum, Xanthium spinosum, Portulaca oleracea, Flaveria trinervia, Chenopodium spp., Eragrostis spp., and

Launaeaintybacea were among weed species equally important in the area with the weed species nationally categorized as problematic weeds; but not yet got attention.

Tablel Number of weed families identified and number of species they comprise

\begin{tabular}{|c|c|c|c|c|c|}
\hline No. & Family & Specie & No. & Family & Specie \\
\hline 1 & Asteraceae & 15 & 15 & Boraginaceae & I \\
\hline 2 & Poaceae & 14 & 16 & Capparidaceae & I \\
\hline 3 & Chenopodiaceae & 6 & 17 & Commelinaceae & I \\
\hline 4 & Solanaceae & 5 & 18 & Cyperaceae & I \\
\hline 5 & Amaranthaceae & 5 & 19 & Euphorbiaceae & I \\
\hline 6 & Fabaceae & 5 & 20 & Orobanchaceae & I \\
\hline 7 & Polygonaceae & 3 & 21 & Papaveraceae & I \\
\hline 8 & Brassicaceae & 2 & 22 & Plantaginaceae & I \\
\hline 9 & Convolvulaceae & 2 & 23 & Primulaceae & I \\
\hline 10 & Lamiaceae & 2 & 24 & Resedaceae & I \\
\hline 11 & Malvaceae & 2 & 25 & Scrophulariaceae & I \\
\hline 12 & Portulacaceae & 2 & 26 & Verbenaceae & I \\
\hline 13 & Acanthaceae & 1 & 27 & Zygophylaceae & I \\
\hline 14 & Apiaceae & I & Total & & 78 \\
\hline
\end{tabular}

Table 2 The top twenty weed species of the study area in terms of their importance value (IV)

\begin{tabular}{|c|c|c|c|c|c|}
\hline Rank & Scientific name & RF (\%) & RA (\%) & RD (\%) & IV (\%) \\
\hline I & Nicandra physaloides L. & 73 & 7 & 13 & 92 \\
\hline 2 & Galinsoga parviflora Cav. & 64 & 18 & 7 & 89 \\
\hline 3 & Cyperus rotundus $\mathrm{L}$. & 64 & 18 & 4 & 85 \\
\hline 4 & Xanthium strumarium L. & 54 & 3 & 8 & 65 \\
\hline 5 & Amaranthus hybridus L. & 56 & 2 & 6 & 64 \\
\hline 6 & Setaria verticilata $\mathrm{L}$. & 50 & 3 & 3 & 55 \\
\hline 7 & Datura stramonium L. & 48 & I & 6 & 55 \\
\hline 8 & Argemone Mexicana Sweet. & 43 & 5 & 4 & 52 \\
\hline 9 & Xanthium spinosum L. & 43 & I & 3 & 48 \\
\hline 10 & Erucastrumabyssinicum (A. Rich.) OE Schulz. & 45 & I & 2 & 48 \\
\hline 11 & Portulaca oleracea L. & 35 & 6 & 3 & 44 \\
\hline 12 & Cynodon nlemfuensis Vanderyst. & 35 & 3 & 2 & 41 \\
\hline 13 & Parthenium hysterophorus $\mathrm{L}$. & 33 & 4 & 4 & 41 \\
\hline 14 & Flaveria trinervia (Spreng.) C. Mohr & 34 & 3 & 3 & 39 \\
\hline 15 & Setaria incrassate (Hochst.) Hack. & 34 & 2 & 2 & 37 \\
\hline 16 & Eragrostis cilianensis All. & 33 & I & 1 & 34 \\
\hline 17 & Amaranthus spinosus $\mathrm{L}$. & 26 & 4 & 2 & 32 \\
\hline 18 & Eleusine indica $\mathrm{L}$. & 27 & I & 2 & 30 \\
\hline 19 & Orobanche minor Smith. & 23 & 4 & 2 & 29 \\
\hline 20 & Chenopodium opulifolium Schrader ex Koch \&Ziz. & 24 & 3 & 2 & 29 \\
\hline
\end{tabular}

Citation: Terfa AE. Weed species diversity, distribution and infestation trend in small scale irrigated vegetable production area of mid-rift-valley of Ethiopia. Biodiversity Int J. 2018;2(I):75-8I. DOI: 10.15406/bij.2018.02.00047 
Among the weed species recorded, two parasitic weeds; namely Orobanche spp and Cuscuta spp. were found prominent. Orobanche weed was found attached mainly on tomato and some alternative host weeds. Cuscuta weed was previously not found attached on vegetable crops rather on border weeds like Xanthium strumarium and Hypoestes forskaolii, but during 2015 GC assessment it was found invading onion of many farmers. Information from field visit and raised on discussion confirmed that no action has been taken to limit invasion of Orobanche weed due to the assumption that hand pulling could cause damage on root zone of the host and encourage multiplication of parasite weed Orobanche.
Similar to Izquierdo et al. ${ }^{11}$ investigation, the similarity(S), diversity (H') and dominancy (D) of weed species were found variable from crop field to crop field indicating the variability of weed management intensity among crops. The high diversity, dominancy and abundance values of weed species in tomato has been as a result of the weeds made to thrive long period in the field due to the farmers assumption that physical contact in late ages of tomato aggravates disease occurrence. Kale was found a crop with relatively high intensive management because of the frequent harvesting nature of the crop and as a result it was found with low weed abundance, diversity and dominance values (Table 3 ).

Table 3 Distribution and diversity of the weed in major crop field of the study area

\begin{tabular}{llllll}
\hline Crop & Mean & Similarity (S) & Evenness (E) & Diversity (H) & Dominancy (D) \\
\hline Haricot bean & 8 & 34 & 0.65 & 2.287 & 0.795 \\
Kale & $\mathrm{I}$ & 15 & 0.77 & 2.091 & 0.829 \\
Maize & 8 & 37 & 0.62 & 2.227 & 0.749 \\
Onion & 10 & 31 & 0.68 & 2.33 & 0.839 \\
Hot pepper & $\mathrm{I}$ & 25 & 0.7 & 2.257 & 0.76 \\
Tomato & 76 & 72 & 0.69 & 2.934 & 0.903 \\
\hline
\end{tabular}

The dominant weeds of the study district and common irrigation sites were identified. In Adami Tulu district Amaranthus hybridus, Nicandra physaloides, Galinsoga parviflora, Flaveria trinervia and Galinsoga parviflora were found dominant at Haleku, Golba, Abne Germama, Edo Gojola and Elka Chelemo irrigation sites respectively during 2013 growing season. During 2015 growing season, Nicandra physaloides was found over dominated Amaranthus hybridus, at Haleku, Parthenium hysterophorus was found over dominated Galinsoga parviflora and Flaveria trinervia over dominated Galinsoga

Table 4 Weed species dominancy trend in the area within three years (2013 \& 2015) parviflora at Abne Germama and Elka Chelemo respectively. In Dugda district Galinsoga parviflora, Verbesina encelioides, Cynodon nlemfuensis and Xanthium strumarium were found the dominant weeds of the area. Galinsoga parviflora was found over dominated by Nicandra physaloides at Girris a while Nicandra physaloides and Verbesina encelioides were found dominated by Cynodon nlemfuensis, and Xanthium strumarium at Korke Adi and Dodota Dembel respectively in Bora district (Table 4).

\begin{tabular}{|c|c|c|c|c|c|}
\hline \multirow[t]{2}{*}{ District } & \multirow[t]{2}{*}{ Sample Sites } & \multicolumn{2}{|l|}{ Weed Species } & \multicolumn{2}{|c|}{ RD (\%) } \\
\hline & & 2013 & 2015 & 2013 & 2015 \\
\hline & Haleku & Amaranthus hybridus & Nicandra physaloides & 19 & 21 \\
\hline & & Cynodon nlemfuensis & Amaranthus hybridus & 11 & 11 \\
\hline & & Galinsoga parviflora & Galinsoga parviflora & 11 & 11 \\
\hline & Golba & Nicandra physaloides & Nicandra physaloides & 34 & 14 \\
\hline & & Cynodon nlemfuensis & Datura stramonium & 8 & 9 \\
\hline & Abne Germama & Galinsoga parviflora & Parthenium hysterophorus & 25 & 22 \\
\hline \multirow[t]{7}{*}{ Adami Tulu } & & Portulaca oleracea & Portulaca oleracea & 14 & 11 \\
\hline & & Xanthium spinosum & Chenopodium opulifolium & 14 & 9 \\
\hline & Edo Gojola & Flaveria trinervia & Flaveria trinervia & 12 & 11 \\
\hline & & Chenopodium murale & Chenopodium murale & 7 & 11 \\
\hline & Elka Chelemo & Galinsoga parviflora & Flaveria trinervia & 19 & 17 \\
\hline & & Xanthium strumarium & Datura stramonium & 13 & 14 \\
\hline & & Nicandra physaloides & Chenopodium murale & 13 & 8 \\
\hline
\end{tabular}




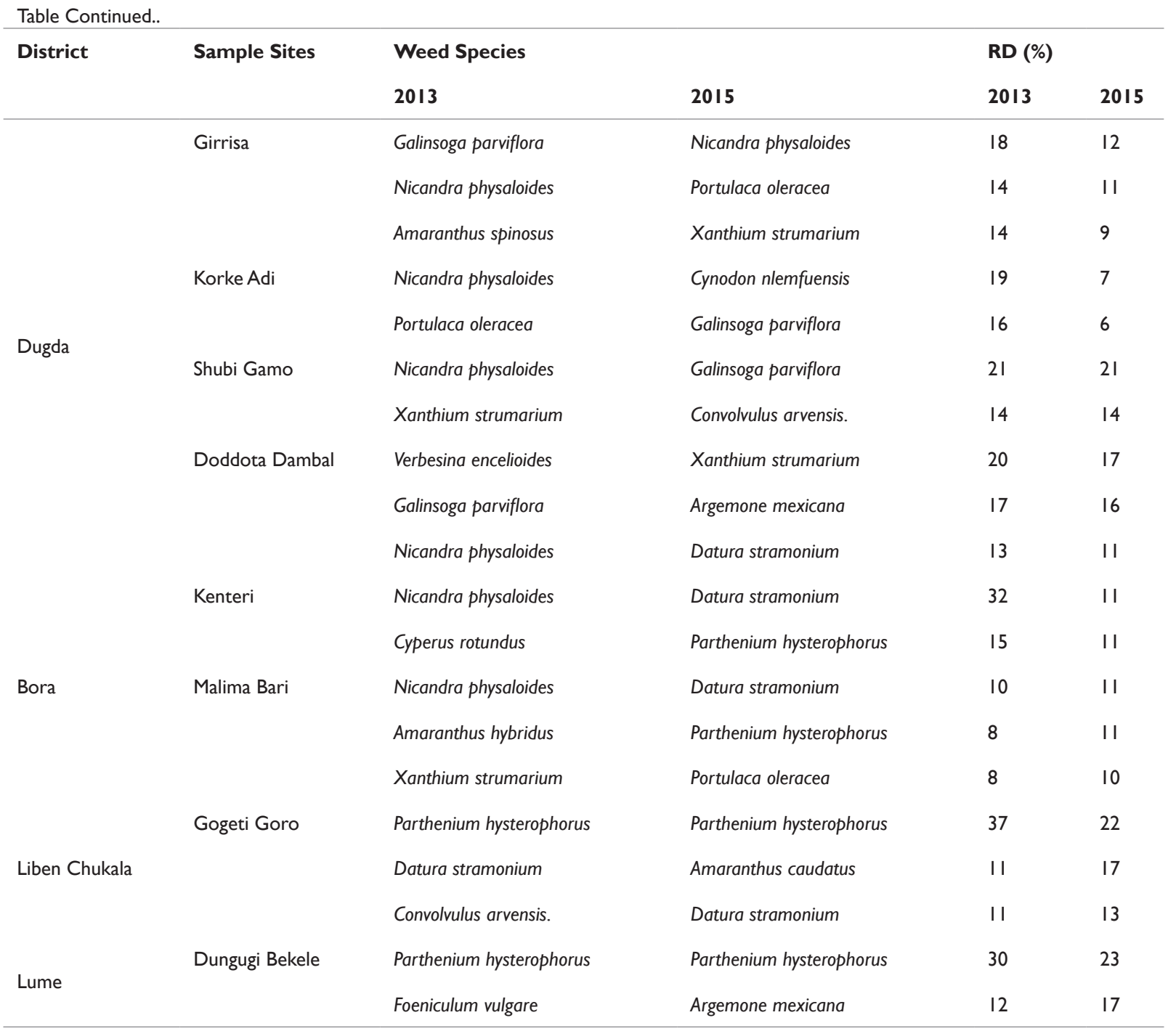

\section{Weeds of miscellaneous contemplation}

No plant is a weed in nature; but human activities create weed and weed problem. Based on that plants which their undesirable qualities outweigh their good points in agriculture have been considered as weeds. No one intentionally sow weeds, but they are well adapted to the environment hold by humans and have been co-existing associated with crops since the origin of agriculture. In perspective of crop protection, weeds are undesirable plants which have negative competitive impact on crops and needed to be controlled, in an economical and practical way, in order to produce food, feed, and fiber for humans and animals. Weeds are plants serving as reservoirs of most crop viruses and their insect and nematode vectors, and of pathogenic fungi and bacteria in addition to their direct competition effect in crop growth. ${ }^{12}$ On other side weeds can also play a role of reducing the risk of disease and pest epidemics in addition to their contribution for the resource base of the rural community in providing a secondary source of foods, medicines and insecticides if their diversity maintained in agriculture. Portulaca spp. are among noxious weeds difficult to control because of their fast growth rate once infested the field, but, used as a famine food even in southern part of Ethiopia. ${ }^{13}$ Portulaca oleracea and Amaranthus spp. were used in Wollo Ethiopia, as a relief from famine during 1984 drought, ${ }^{14}$ still the weeds have been challenging the livelihood of the community neither controlled nor domesticated. People of the study area also raised positive values of weeds like using as feed resource for their livestock, using as supplemental food for their family during the food shortage and for medicinal purpose.

Some weed species which scored low importance value (IV) were raised during farmer's group discussion as very problematic weed in influencing the livelihood of the community. Amaranthus spinosus, Tribulus cistoides, Euphorbia schimperian, Sorghum arundinacium, Acanthospermum hispidum, Amaranthus hybridus, Parthenium hysterophorus, Snowdenia polystachya and Xanthium spinosum were raised as weeds known by poisoning livestock in the area. Foeniculum vulgare, Orobanche minor, Parthenium hysterophorus and Portulaca oleracea were categorized among weeds resistant to herbicide. Portulaca oleracea, Argemone mexicana, Orobanche minor, Chenopodium murale, Verbesina encelioides, Parthenium hysterophorus, Flaveria trinervia and Launaeaintybacea were listed among weed species currently highly invading the area. Nicandra physaloides, Xanthium strumarium, Parthenium hysterophorus, Datura stramonium and Erucastrumabyssinicum were marked as weeds serving as alternate host for either insects or disease of vegetables (Table 5). Study carried out in Chile to identify weeds serving as alternate host of cucurbit mosaic virus (CMV), tomato spotted wilt virus (TSWV) and potato virus Y (PVY), Datura, Nicandira and Solanum nigrum were identified as alternate host of CMY and PVY and Galinsoga and Sonchus weeds were identified as alternate host of TSWV while Chenopodium was found responsible to transmit all viruses. ${ }^{15}$ 
Table 5 Weeds species categorized based on information from the farmers

\begin{tabular}{|c|c|c|c|c|c|}
\hline Weed species & $\begin{array}{l}\text { Poisoning } \\
\text { livestock }\end{array}$ & $\begin{array}{l}\text { Resistant to } \\
\text { herbicide }\end{array}$ & $\begin{array}{l}\text { Currently on } \\
\text { invasion }\end{array}$ & $\begin{array}{l}\text { Limited to arable } \\
\text { land }\end{array}$ & $\begin{array}{l}\text { Serving as alternate hosts } \\
\text { of pest }\end{array}$ \\
\hline Hypoestes forskaolii & & $*$ & & & \\
\hline Amaranthus spinosus & $* * *$ & & & & \\
\hline Foeniculum vulgare & & $*$ & $*$ & & \\
\hline Datura stramonium & & & & & $*$ \\
\hline Flaveria trinervia & & & $*$ & $*$ & \\
\hline Launaeaintybacea & & $*$ & $*$ & & \\
\hline Parthenium hysterophorus & $*$ & $*$ & $*$ & & $*$ \\
\hline Verbesina encelioides & & & $*$ & & \\
\hline Xanthium strumarium & & & $*$ & & $*$ \\
\hline Erucastrumabyssinicum & & & & $*$ & $*$ \\
\hline Chenopodium murale & & & $*$ & $*$ & $*$ \\
\hline Chenopodium opulifolium & & & $*$ & $*$ & $*$ \\
\hline Cyperus rotundus & & $*$ & $*$ & & \\
\hline Euphorbia schimperiana & $* *$ & $*$ & & & \\
\hline Orobanche minor & & $*$ & $*$ & & \\
\hline Argemone mexicana & & $*$ & $*$ & $*$ & \\
\hline Cynodon nlemfuensis & & $*$ & & & \\
\hline Setaria incrassata & & $*$ & $*$ & & $*$ \\
\hline Snowdenia polystachya & $*$ & $*$ & & & \\
\hline Portulaca oleracea & & $*$ & $*$ & $*$ & $*$ \\
\hline Eragrostis cilianensis & & & & $*$ & \\
\hline Nicandra physaloides & & & & $*$ & $*$ \\
\hline Xanthium spinosum & $*$ & & & & \\
\hline Tribulus cistoides & $* *$ & & & & \\
\hline
\end{tabular}

***, Commonly known; **, Partially known; *, Less commonly known

The farmers' opinion is coincided with the study result of Alemu et al. (2002) that identified Datura stramonium and Nicandra physaloides as potential alternate hosts of Capsicum viruses, Cucumber mosaic virus, tomato mosaic virus and potato virus in mid rift valley of Ethiopia. Study made in Cyprus confirmed that weed in family Chenopodiaceae, Compositae, Convolvulaceae, Cruciferae, Euphorbiaceae, Fabaceae, Malvaceae, Orobanchaceae, Plantaginaceae, Solonaceae, Umbeliferae and Primulaceae were identified as alternate host of tomato yellow leaf curl virus (TYLCV). ${ }^{16}$ More than $60 \%$ of the study area weeds identified were comprised in the above listed plant families indicating, almost all weed species have significant contribution for the aggravation of vegetable pests problem.

\section{Factors driving weed invasion in the area}

Limited use of crop rotation, limited use of herbicide in vegetable fields, unavailability of species specific herbicides and poor field sanitation as a whole were observed as a driving force for the ever expansion of weed invasion in the area. The fields were made to be visited by livestock after harvest and only those preferable weeds were grazed and those unpalatable were left on field and seed to their potential till the field required for the other round cultivation. Herbicides are only adopted for controlling broad leaved weeds in cereals (Teff and wheat). No tradition of field sanitation after the crop has been harvested until the land needed for another round planting. Weeds simply grow and bear their seed using the residual moisture and fertilizer. Weed seeds germination and growth is year round in irrigated vegetable production areas. In tomato field specifically, weeding activity terminated immediately after flowering due to the assumption that weeding aggravates disease severity in the field. Till the final harvest the field totally covered by the weed. After harvest the field left abandoned and the weeds complete their lifecycle and shed their seed to the soil.

\section{Weeds of considerable cost implications}

Information obtained through personal discussion with some farmers elucidated that some weeds species inevitably incur extra costs in vegetable farms. Amaranthus spinosus and Xanthium spinosum are 
among weeds need special negotiation for extra payment of up to 50 $70 \%$ from the usual labor cost rate. Laborers are not willing to work fields infested with these two special weeds in contractual agreement unless with daily basis work. The other weed with considerable cost implication due to its fast growth rate was Portulaca oleracea. As information obtained from farmers dictated, field infested with Portulaca oleracea demand regular weeding as compared to the other weeds.

\section{Conclusion and recommendations}

This study revealed that weeds have been imposing greater challenge to vegetable producing farmers, and consumers of the produce. Weeds are contributing in production cost amplifying through its direct labour consumption and indirectly by harboring insect and disease pests for which huge expense on pesticide. All weeds are not equally problematic in agriculture. Some weeds in addition to their ecological benefit they provide medicinal, food and insecticidal uses. Farmers clearly know which weed specie highly challenging their livelihood. Therefore, strategies in which the noxious weeds controlled and the beneficial maintained in the farm or farm margins should be developed. The fragmented land holding of the area is also another impediment in effective weed control strategy. Based on either the crop requirement or the interest of the producer, when one farmer field is under production the other neighboring farmer remain abandoned. At that time disease inoculums and weed seeds coming from the adjacent fields are the most significant barrier to effective disease, insect and weed control. Therefore there should be legal ground that enforces the cooperation between the neighboring land owners for effective weed and then insect and disease management. The farming community of the study area, even though they didn't appreciate the existence of weeds in their farm; they have been doing less effort to control the expansion of weed population. As a result of the weak weed management; the existing practice is found encouraging the ever increasing of weed invasion. No one was found clearing his idle field for the purpose of weed control. All were observed starting weed clearing only when the land has been required for cultivation. To overcome weed damage, preventing weeds presence in the field and field margins should always be taken as a strategy.

Farmers of the study area recognized cultivating the same crop year after year or with short period rotation. This type of practice favors the invasion of the field by some weed species as a result of the cultural practice and herbicides used for that crop. Tomato and onion are the dominant crop cultivated in the study area. As a result the buildup of pests of the particular crops is also very high. To overcome the problem farmers apply cocktail of pesticides with in an interval of 3-5day which finally ends up to greater than 36 times spray within the single cropping period which is becoming worsen and worsen from time to time. Therefore, shift in crop type and pest management strategy should be devised to combat the ever worsening of the problem. To solution the controversy on weed management strategies, an integrated crop protection system should be to the needs of the resource-poor farmer, which weeds are managed in such a way their biodiversity is maintained and the more useful species retained within the field or field margin (Appendix 1).

\section{Acknowledgements}

Oromia Institute of Agricultural Research is highly acknowledged for funding this study through Adami Tullu Agricultural Research
Center. The contribution of Adami Tullu Agricultural Research Center Horticulture Research Team in collection of valuable data for this study is also highly acknowledged.

\section{Conflict of interest}

Author declares there is no conflict of interest in publishing the article.

\section{References}

1. Alemayehu N, Hoekstra D, Berhe K, et al. Irrigated vegetable promotion and expansion: The case of Ada'a District, Oromia Region, Ethiopia. IPMS/ILRI Case Study Report, Addis Ababa, Ethiopia; 2010.

2. Emana B, Afari-Sefa V, Dinsa FF, et al. Characterization and assessment of vegetable production and markets system in humid tropics of Ethiopia. Quarterly J Int Agri. 2015;54(2):163-187.

3. Hengsijk H, Jansen H. Agriculture and Development in the Central Ethiopian Rift valley: A desk study on water-related issues and knowledge to support a policy dialogue. Plant Research International BV Wageningen, Netherlands; 2006.

4. Amera T, Abate A. An Assessment of the Pesticide Use, Practice and Hazards in the Ethiopian rift Valley. Africa Stockpiles Programme, UK; 2008. p. 1-67.

5. Upadhyay RK, Baksh H, Patra DD, et al. Integrated weed management of medicinal plants In India. Int J Med Arom Plants. 2011;1(2):51-56.

6. Palumbo JC. Insect-weed interactions in vegetable crops. VegIPM Update. 2013;4(13):1-3

7. Maynard DN, Hochmuth GJ. Knott's handbook for vegetable growers. 5th ed. Hoboken, John Willey and Sons Inc, New jersey, USA; 2007.

8. Hillocks RJ. The potential benefits of weeds with reference to small holder agriculture in Africa. Integrated Pest Management Reviews. 1998;3(3):155-167.

9. Yung L, Chandler J, Heverhals M. Effective weed management, collective action and land ownership change in western Montana. Weed Society of America. 2015;8(2):193-202.

10. Bekele E, Azerefegne F, Abate T. Facilitating the Implementation and Adoption of Integrated Pest Management (IPM) in Ethiopia. Planning Workshop from October 13-15, 2003 Melkassa Agricultural Research Center, EARO. Jointly Organized by Association for Advancement of IPM (ASAI) \& Ethiopian Agricultural Research Organization (EARO), Ethiopia; 2006.

11. Izquierdo J, Blanco-Moreno JM, Chamorro L, et al. Special distribution of weed diversity within a cereal field. Agron Sustain Dev. 2009;29(3):491-496.

12. Jenkinson P, Parry DW. Isolation of Fusarium species from common broad-leaved weeds and their pathogenicity to winter wheat. Mycol Res. 1994;98(7):776-780.

13. Guinand Y, Lemessa D. Wild food plants in Southern Ethiopia. A report from: UNDP Emergencies Unity for Ethiopia, Ethiopia; 2000.

14. Rahmato D. Peasant survival strategies in Ethiopia. Disasters. 1988;12(4):326-344.

15. Ormeno JN, Sepulveda PR. Presence of different sweet pepper (Capsicum annum L.) viruses on associated weed species. Agricultural Tecnica. 2005;65(4):343-355.

16. Papayiannis LC, Katis NI, Idris MA, et al. Identification of weed hosts of tomato yellow leaf curl virus in Cyprus. The American Phytopathological society. 2011;95(2):120-125. 